\title{
Peningkatan Kemampuan Perempuan dalam Mewujudkan Diversifikasi Pangan Rumah Tangga di Desa Teratak Kecamatan Batukliang Utara, Kabupaten Lombok Tengah
}

\author{
Hayati*, Arifuddin Sahidu, Muktasam, Johan Bachri \\ Fakultas Pertanian, Universitas Mataram, Mataram, Indonesia
}

\section{Article history}

Received: 02 Desember 2019

Revised: 28 Januari 2020

Accepted: 23 Maret 2020

*Corresponding Author:

Hayati

Fakultas Pertanian, Universitas Mataram, Mataram, Indonesia Email:

hayatizakaria75@yahoo.com

\begin{abstract}
Women in Teratak Village, North Batukliang District, Central Lombok Regency are still seen as the main actors in the realization of household food security. Teratak Village, especially Benjor Village, has potential yard and water resources that have not been used optimally as a source of household food and human resources that are united. Therefore, increasing women's abilities are needed.This activity was carried out through a series of extension activities by utilizing the potential of resources are carried out using participatory methods, namely brainstorming, lectures, discussions, games, demonstrations/practices, and competitions to prepare a variety and nutritious food. The implementation of the activities was directly carried out by the team which also acts as a guest speaker, and was also involved private extension workers and civil servant of extension workers in the framework of creating networks and program sustainability. The implementation of extension activities were smoothly and effectively; the women were very enthusiastic to participating in each activity. The results shows that the extention were considered positive and felt very beneficial for women. Women already have groups as a forum for learning and collaboration; and also have increased knowledge, positive attitudes and abilities in realizing the diversification of household food which is characterized by the ability to cultivate vegetables and raising freshwater fish, compile diet and provide diverse and nutritious food.
\end{abstract}

Keywords: consumption; diversification; extension; household; production

Abtrak: Perempuan di Desa Teratak Kecamatan Batukliang Utara Kabupaten Lombok Tengah masih dipandang sebagai pelaku utama perwujudan ketahanan pangan rumahtangga. Desa Teratak, khususnya Dusun Benjor, memiliki potensi sumberdaya lahan pekarangan dan air yang belum dimanfaatkan secara optimal sebagai sumber pangan rumah tangga, dan sumberdaya manusia yang guyub. Oleh karena itu, dibutuhkan peningkatan kemampuan perempuan melalui kegiatan penyuluhan dengan memanfaatkan potensi sumberdaya yanga ada dengan menggunakan metode penyuluhan partisipatif yaitu brainstorming, ceramah, diskusi, permainan, demonstrasi/praktik, dan lomba menyiapkan makanan yang beragam dan bergizi. Pelaksanaan kegiatan secara langsung dilakukan oleh tim pelaksana yang sekaligus sebagai narasumber dan juga melibatkan penyuluh swasta dan penyuluh PNS dalam rangka menciptakan jaringan dan keberlanjutan program. Pelaksanaan kegiatan penyuluhan berjalan lancar dan efektif. Perempuan sasaran penyuluhan sangat antusias berpartisipasi dalam setiap kegiatan. Hasil kegiatan dinilai positif dan dirasakan sangat bermanfaat bagi perempuan, dan kemudian telah memiliki kelompok wanita tani sebagai wadah belajar dan kerjasama; serta memiliki peningkatan pengetahuan, sikap positif dan kemampuan dalam mewujudkan diversifikasi pangan rumahtangga yang dicirikan oleh kemampuan 
melakukan budidaya tanaman sayuran dan ikan air tawar, menyusun menu (diet) dan menyediakan makanan yang beragam dan bergizi.

Kata Kunci: konsumsi; keanekaragaman, penyuluhan; produksi; rumah tangga

\section{PENDAHULUAN}

Pangan merupakan kebutuhan dasar manusia yang paling utama dan bagian dari hak asasi individu. Oleh karenanya, setiap individu dalam rumah tangga harus menkonsumsi makanan yang beragam dan bergizi agar dapat hidup yang sehat dan aktif (World Bank, 2009, Hayati, 2015a). Perwujudan ketahanan pangan rumah tangga dapat dicapai melalui pelaksanaan kegiatan diversifikasi pangan (Hayati, 2018a)

Pada dasarnya diversifikasi pangan mencakup tiga lingkup pengertian yang saling berkaitan, yaitu (1) diversifikasi konsumsi pangan, (2) diversifikasi ketersediaan pangan, dan (3) diversifikasi produksi pangan (Suhardjo, 1998). Undang-undang Pangan Nomor 18 tahun 2012 mendefinisikan diversifikasi pangan sebagai upaya peningkatan ketersediaan dan konsumsi pangan yang beragam dan bergizi seimbang. Upaya diversifikasi pangan rumah tangga memang tidak dapat mengabaikan peran perempuan. Perempuan memiliki peranan yang sangat penting untuk mewujudkan diversifikasi pangan rumah tangga dan mencetak sumber daya manusia yang berkualitas.

Di Indonesia umumnya, Kabupaten Lombok Tengah khususnya, perempuan berperan pada aspek ketersediaan pangan, produksi pangan dan konsumsi pangan, termasuk dalam menyiapkan dan mendistribusikan makanan kepada semua anggota rumah tangga. Hal ini terkait dengan adanya perbedaan peran gender yang berlaku di masyarakat Pulau Lombok, dimana perempuan berperan dalam pelaksanaan pekerjaan pada ranah domestik, sedangkan laki-laki pada ranah publik (Zakaria et al. 2014; Hayati et al. 2015b; Hayati et al. 2018a,b). Akan tetapi, kemampuan perempuan belum memadai untuk meningkatkan diversifikasi pangan rumah tangga. Hal ini ditunjukkan dengan tingkat konsumsi energi (TKE) rumah tangga sebesar 1.726,6 Kkal/kapita/hari adalah di bawah standar nasional dan tergolong sangat rawan pangan (Hayati et al. 2018a, b).

Upaya diversifikasi pangan rumah tangga pada aspek ketersediaan pangan dan produksi pangan telah dilakukan oleh pemerintah melalui program kawasan rumah pangan lestari (KRPL). Namun dalam implementasinya, bentuk kegiatan program KRPL sebatas pemanfaatan lahan pekarangan dengan menanam sayur-sayuran dan buah-buahan serta pemeliharan ternak kecil. Kegiatan penyuluhan terkait dengan konsumsi pangan belum tersentuh melalui program KRPL tersebut (Hayati, 2015a). Rencana Aksi Nasional Pangan dan Gizi 2011-2015, menyatakan bahwa setiap orang harus mengkonsumsi beraneka ragam pangan, karena tidak ada satu jenis pangan yang yang dapat menyediakan gizi bagi seseorang secara lengkap. Melalui konsumsi pangan yang beragam maka kekurangan zat gizi dari suatu jenis pangan akan dilengkapi oleh gizi dari jenis pangan lainnya. Jika setiap orang mengkonsumsi beraneka ragam pangan, Firmanyah (2010) mengatakan akan meningkatkan kualitas sumber daya manusia.

Tingkat diversifikasi pangan rumah tangga yang rendah akan menyebabkan rendahnya kualitas sumber daya manusia. Rendahnya kualitas sumber daya manusia di Desa Teratak ditunjukkan dengan munculnya permasalahan stunting. Rendahnya tingkat diversifikasi pangan rumah tangga disebabkan di antaranya oleh rendahnya kemampuan perempuan sebagai orang yang masih dianggap sebagai pelaku utama perwujudan ketahanan pangan rumah tangga (Hayati et al. 2018a). Oleh karena perempuan memiliki peran yang penting dalam meningkatkan diversifikasi pangan rumah tangga 
maka perempuan harus dipandang sebagai masyarakat yang aktif, memiliki inisiatif, kemauan dan kemampuan dalam upaya mewujudkan rumah tangga yang tahan pangan. Peningkatan kemampuan perempuan secara sosial, manajerial dan teknis berkaitan dengan penyelenggaraan kegiatan penyuluhan (Hayati, 2015a, 2018a). Penyelenggaraan penyuluhan peningkatan kemampuan perempuan sangat efektif jika dilakukan dengan pendekatan kelompok (Hayati, 2015a). Melalui kelompok, diharapkan perempuan memiliki wadah untuk berinteraksi, serta belajar dan bekerjasama.

Analisis situasi di Desa Teratak Kecamatan Batukliang Utara Kabupaten Lombok Tengah menggambarkan bahwa: 1) Terdapat 97 anak yang tergolong stunting; 2) Terdapat potensi lahan pekarangan dan lahan kosong yang luas, air yang melimpah namun belum dimanfaatkan secara optimal sebagai sumber pangan rumah tangga; 3) Belum pernah ada kegiatan penyuluhan mengenai budidaya beragam tanaman sayuran di lahan pekarangan dan lahan kosong dan pentingnya mengkonsumsi pangan yang beraneka ragam dan bergizi bagi setiap individu dalam rumah tangga; 4) Belum terdapat kelompok perempuan yang dapat digunakan sebagai wadah penyuluhan.

Oleh karena itu, kegiatan pengabdian kepada masyarakat mengenai "Peningkatan Kemampuan Perempuan dalam Mewujudkan Diversifikasi Pangan Rumah Tangga di Desa Teratak Kecamatan Batukliang Utara" ditujukan untuk meningkatkan diversifikasi produksi pangan, konsumsi pangan rumah tangga masyarakat di Desa Teratak, Kecamatan Batukliang Utara, Kabupaten Lombok Tengah. Peningkatan diversifikasi pangan rumah tangga ini telah dapat dicapai melalui serangkaian pelaksanaan kegiatan penyuluhan peningkatan kemampuan perempuan baik secara sosial, manajerial maupun teknis.

\section{METODE}

Kegiatan pengabdian kepada masyarakat dilakukan di Dusun Benjor, Desa Teratak, Kecamatan Batukliang Utara, Kabupaten Lombok Tengah. Pencapaian tujuan kegiatan pengabdian kepada masyarakat ini menggunakan metode penyuluhan yang partisipatif, yaitu brainstorming, ceramah yang partisipatif, tanyajawab, diskusi, permainan; dan demonstrasi, praktik, dan lomba menyusun menu serta menyiapkan makanan yang beragam, bergizi dan seimbang. Materi penyuluhan disampaikan langsung oleh tim pelaksana yang bertindak sekaligus sebagai narasumber dan fasilitator. Selain itu, juga melibatkan penyuluh swasta, penyuluh swadaya dan penyuluh PNS dalam rangka menciptakan dan menjalin hubungan atau jaringan kerjasama untuk keberlanjutan program.

Dalam setiap tahapan pelaksanaan kegiatan pengabdian kepada masyarakat ini, bentuk partisipasi perempuan yang diharapkan adalah tidak hanya partisipasi secara fisik yaitu kehadiran dan buah pikiran, seperti aktif dalam menyumbangkan ide, gagasan, pendapat, pengalaman. Melainkan, didorong juga untuk menumbuhkan atau memunculkan partisipasi dalam bentuk tenaga, materi (uang), alat-alat kerja, dan keterampilan.

Adapun tahapan pelaksanaan kegiatan pengabdian kepada masyarakat di Dusun Benjor, Desa Teratak Kecamatan Batukliang Utara adalah sebagai berikut:

a. Tahap persiapan yaitu: a) Mendata dan mengumpulkan informasi tentang peran perempuan calon sasaran binaan; b) Mengidentifikasi permasalahan dan solusi pemecahan masalah; 3) Sosialisasi program peningkatan diversifikasi pangan rumah tangga.

b. Tahap pelaksanaan kegiatan penyuluhan peningkatan kemampuan sosial: a) Workshop pembentukan dan penguatan kelompok binaan; b) Penyuluhan mengenai pentingnya keberadaan kelompok bagi perempuan; c) Penyuluhan mengenai konsep diri. 
c. Tahap pelaksanaan kegiatan peningkatan kemampuan manajerial workshop penyusunan perencanaan dan evaluasi kegiatan peningkatan diversifikasi pangan rumah tangga.

d. Tahap pelaksanaan kegiatan peningkatan kemampuan teknis pemanfaatan lahan pekarangan: a) Penyuluhan budidaya tanaman sayuran dan buah dan memelihara ikan air tawar; b) Penyuluhan menyediakan makanan yang beragam dan bergizi; c) Lomba menyusun menu dan menyediakan makanan sehat, bergizi dan berimbang.

Tahap evaluasi dilakukan pada tahap persiapan, pelaksanaan, dan akhir program kegiatan.

\section{HASIL DAN PEMBAHASAN}

Pembahasan terhadap hasil kegiatan pengabdian kepada masyarakat diuraikan menurut tahapan pelaksanaan kegiatannya yaitu tahap persiapan, pelaksanaan dan evaluasi.

\section{Tahap persiapan.}

Hasil pengumpulan data dan informasi memberikan gambaran mengenai peran yang dijalankan perempuan adalah peran sebagai istri yang memiliki pekerjaan sebagai guru, kader posyandu, wirausahawan, dan buruh tani; janda dengan pekerjaan sebagai buruh tani, istri yang tidak bekerja karena memiliki bayi atau balita. Beragamnya peran perempuan di Dusun Benjor ini tidak menjadi kendala bagi mereka untuk berkumpul karena di antara mereka masih memiliki hubungan kekeluargaan. Namun, mereka belum memiliki wadah untuk belajar, bekerjasama, dan mengembangkan usaha. Selama ini, mereka memiliki akses yang rendah terhadap informasi mengenai: a) menanam beragam sayuran di lahan pekarangan dan memelihara ikan air air sebagai sumber pangan rumah tangga mereka; b) susunan jenis pangan dan jumlah konsumsi pangan sesuai tahapan dan kebutuhan bayi, balita, remaja, ibu hamil dan ibu menyusui, orang dewasa laki-laki dan perempuan, serta pentingnya makanan yang beragam dan bergizi bagi tubuh dan kesehatan setiap individu anggota rumah tangga.

Perempuan di Dusun Benjor sama sekali belum pernah mengikuti kegiatan penyuluhan mengenai pemanfaatan lahan pekarangan. Padahal, lahan di Dusun Benjor tergolong sangat subur tetapi sebagian besar lahan pekarangan mereka tidak ditanami beragam tanaman sayuran dan buah. Selain itu, di Dusun Benjor juga terdapat seorang "Penyuluh Swadaya" dan memiliki kompetensi terkait dengan budidaya tanaman sayuran baik dalam bedengan maupun polybag. Namum, transfer informasi belum pernah terjadi di antara mereka. Sebagian besar rumah tangga mereka belum memanfaatkan potensi air itu untuk memenuhi kebutuhan pangan hewani rumah tangga. Hal ini dikarenakan tidak memiliki biaya untuk membuat kolam dan memelihara ikan.

Rendahnya akses perempuan terhadap informasi terkait mengenai pentingnya makanan yang beragam dan bergizi bagi tubuh dan kesehatan setiap individu dalam rumah tangga, terutama ibu hamil, bayi, anak dan remaja disebabkan karena belum pernah ada kegiatan penyuluhan mengenai pentingnya mengkonsumsi pangan yang beraneka ragam dan bergizi bagi setiap individu dalam rumah tangga. Meskipun di antara mereka ada yang berperan sebagai "Kader Posyandu" namun transfer informasi mengenai kesehatan, konsumsi pangan dan gizi yang telah diperoleh Kader Posyandu tidak pernah dilakukan kepada masyarakat di sekitar rumahnya atau pada keluarganya. Hal ini terkait dengan tugas kader hanya terbatas di posyandu dengan kegiatan penimbangan balita dan memberikan makanan tambahan. Fungsi posyandu belum diperluas menjadi posyandu keluarga, dan 
kemampuan Kader Posyandu dalam berkomunikasi untuk mentransfer kembali informasi masih rendah.

Untuk mengatasi permasalahan di atas, pembentukan kelompok bagi perempuan sebagai pelaku utama perwujudan diversifikasi pangan rumah tangga sangat diperlukan. Keberadaan kelompok wanita sangat penting sebagai penghantar (katalis) inter dan antara masyarakat desa dengan masyarakat luar desa, sebagai wadah membangun diri dan komunitasnya, wadah belajar, wadah menyelesaikan permasalahan, wadah mengelola inovasi, dan wadah menuju perubahan yang lebih baik (Setiawan 2012). Pendapat ini sejalan dengan Sumardjo (2012) yang mengatakan bahwa keberadaan kelompok wanita tani ke depan akan semakin penting jika efektif mengemban fungsi sebagai: a) Wahana kerja sama baik di antara sesama anggota atau dengan kelompok lain sehingga efisien dan efektif bagi wanita tani dalam menghadapi tantangan, ancaman, hambatan, dan gangguan, terutama dalam membangun posisi tawar dan nilai petani dalam sistem agribisnis; b) Media belajar dan pembelajaran bagi wanita tani dalam meningkatkan kompetensinya menuju kemandirian berusaha tani agar terjadi peningkatan produktivitas, pendapatan dan kesejahteraan; c) Media mengembangkan usaha bersama mencapai skala usaha tani yang efisien dan efektif dalam mewujudkan kualitas, kuantitas maupun kontinuitas usaha.

Berdasarkan hasil sosialisasi program pengabdian kepada masyarakat yang telah dilakukan, dengan dukungan yang sangat tinggi dari Kepala Dusun Benjor, perempuan di Dusun Benjor sepakat dan sangat antusias untuk membentuk dan memiliki kelompok wanita tani sebagai wadah untuk belajar, bekerjasama dan berusaha.

\section{Tahap pelaksanaan}

a. Proses kegiatan penyuluhan mengenai peningkatan kemampuan sosial perempuan Dusun Benjor telah berlangsung dengan sangat baik dan efektif dimana perempuan peserta kegiatan sangat aktif dan antusias selama proses kegiatan.

1) Kegiatan workshop pembentukan dan penguatan kelompok yang telah dilakukan telah berhasil membentuk kelompok dengan nama "Kelompok Wanita Tani (KWT) Mekar Indah", dan berhasil dalam menyusun dan menyepakati kepengurusan dengan struktur organisasi KWT Mekar Indah.

2) Penyuluhan mengenai pentingnya keberadaan kelompok bagi perempuan telah berjalan dengan baik. Peserta memahami bahwa fungsi kelompok adalah sebagai: 1) media belajar dan pembelajaran utnuk meningkatkan pendapatan dan kesejahteraan, 2) wahana bekerja sama dalam kelompok dan dengan kelompok lain, dan 3) media mengembangkan usaha bersama agar lebih efisien dan efektif. Peserta bersepakat untuk melakukan kegiatan bersama dalam kelompok terkait dengan produksi pangan yaitu menanam sayuran di lahan pekarangan dan memelihara ikan air tawar.

3) Sosialisasi mengenai keberadaan KWT Mekar Indah kepada Penyuluh Pertanian Lapangan (PPL) PNS Desa Teratak, yaitu Bapak Burhannuddin dan Penyuluh Swadaya Dusun Benjor, yaitu Bapak Nur Alim dilakukan untuk mendukung keberlanjutan program. PPL PNS memberikan solusi untuk melegalkan keberadaan KWT Mekar Indah dengan mendaftarkan diri ke Dinas Pertanian agar kemudian KWT Mekar Indah dapat diperhatikan dan dibina oleh pemerintah. Keberadaan Penyuluh Swadaya telah meningkatkan motivasi peserta untuk lebih termotivasi menanam sayuran di lahan pekarangan. 
4) Permainan mengenai konsep diri untuk membetuk sikap assertif anggota kelompok agar memiliki kepercayaan diri yang tinggi dan keyakinan yang kuat serta kemampuan yang tinggi dalam berinteraksi, berpendapat dan bekerja sama antara sesama anggota kelompok dan di luar kelompok. Pada permainan ini, peserta diminta untuk menuliskan nama pada selembar metaplan, kemudian peserta diminta untuk memberikan kata sifat yang positif dari inisial namanya tersebut. Lalu, secara bergiliran, peserta diminta untuk memperkenalkan diri dengan menyebutkan "Nama" diikuti dengan "kata sifat positif" yang telah ditentukan. Hal ini penting untuk membangun suasana yang positif bagi kelompok. Semua peserta sangat antusias, senang dan semangat dalam berproses, serta berhasil memberikan kata sifat yang positif atas inisial nama atau nama panggilannya, seperti contoh dalam tabel berikut.

Tabel 1. Daftar kata sifat positif berdasarkan inisial nama anggota kelompok

\begin{tabular}{ccc}
\hline Nama & Inisial nama panggilan & Kata Sifat \\
\hline Lukluil maknun & $\mathrm{L}$ & Luar biasa \\
Faizah & $\mathrm{F}$ & Fleksibel \\
Sri Handayani & $\mathrm{S}$ & Serius \\
Hilwati & $\mathrm{H}$ & Hebat \\
Juahiriyah & $\mathrm{J}$ & Juara \\
Madda Elyana & $\mathrm{M}$ & Mandiri \\
Aisyah & $\mathrm{A}$ & Asyik \\
Rauhun & $\mathrm{R}$ & Ramah \\
\hline
\end{tabular}

b. Proses kegiatan penyuluhan peningkatan kemampuan manajerial yang telah dilakukan adalah workshop penyusunan rencana dan evaluasi program diversifikasi pangan rumah tangga menghasilkan susunan rencana kerja kelompok yaitu pemanfaatan lahan pekarangan dengan menanam beragam tanaman sayuran di polybag, bedengan bahkan ada yang menanam di lahan sawah. Adapun jenis sayuran yang ditanama adalah sawi hijau, pokcoy, bayam, kangkung, terung panjang, terung bulat, kacang panjang, oyong, kol, dan kembang kol. Mereka bekerja sama dalam membuat bedengan tersebut. Selain itu, disepakati juga oleh sebagian besar peserta yang belum memiliki kolam untuk mencoba memelihara ikan di dalam keramba yang diletakkan pada kolam milik salah seorang peserta, sebagai sumber protein pangan hewani rumah tangga. Namun, dalam perkembangannya berdasarkan hasil evaluasi kelompok, kelompok berencana memelihara ikan di kolam. Kolam kelompok dibuat pada lahan salah seorang anggota kelompok. Anggota kelompok membangun kesepakatan berpartisipasi dalam bentuk materi dengan membayar iuran untuk keperluan usaha pemeliharaan ikan di kolam. Uang iuran terkumpul, meskipun dalam jumlah yang kecil, digunakan biaya upah buruh, pembelian pipa saluran air, plastik, dan pakan ikan. Tim penyuluh memberikan stimuli bantuan bibit ikan dan pakan.

c. Penyuluhan peningkatan kemampuan teknis adalah penyuluhan pembibitan dan penanaman tanaman sayuran dan buah, pentingnya memelihara ikan air tawar sebagai sumber pangan rumah tangga, serta pentingnya mengkonsumsi pangan yang beragam, bergizi dan berimbang bagi setiap individu dalam rumah tangga. Secara khusus, pelaksanaan penyuluhan mengenai konsumsi pangan pangan yang beragam dan bergizi dilakukan setiap saat oleh Tim Penyuluh. Misalnya, ketika saat pertemuan, tim menyediakan konsumsi makanan yang beragam dan bergizi sambil melakukan penyuluhan mengenai pentingnya pangan dan gizi serta cara membuatnya. Cara ini sangat efektif untuk meningkatkan pengetahuan, pemahaman dan keterampilan peserta. 
1) Peserta memahami dan mampu melakukan pembibitan dan penanaman tanaman sayuran di lahan pekarangan rumah di polybag dan bedengan. Peserta sangat antusias mendengarkan penjelasan penyuluh mengenai cara pembibitan tanaman sayuran. Keberadaan penyuluh swasta dari perusahaan benih telah berkontribusi pada kelompok dalam hal transfer informasi secara langsung, melalui media cetak, yaitu leaflet cara budidaya tanaman sayuran, dan memberikan bantuan benih. Selain itu, peserta juga memahami dan mampu melakukan penanaman tanaman sayuran. Kegiatan ini merupakan pengalaman dan pembelajaran yang begitu sangat mengesankan bagi peserta karena merupakan pengalaman baru menanam sayuran di bedengan. Penanaman yang dilakukan kelompok juga telah memberikan hasil dimana kelompok melakukan panen tanaman sayuran sawi pokcoy.

2) Peserta juga telah mampu memelihara ikan air tawar dalam keramba di kolam salah satu anggota kelompok sebagai sumber pangan hewani. Memelihara ikan dalam keramba karena kelompok belum mendapatkan lahan dan tidak memiliki modal. Namun, kemudian cara ini telah memberikan pembelajaran, memotivasi dan menimbulkan gagasan peserta untuk segera memiliki kolam kelompok.

Adapun gambar pelaksanaan kegiatan sosialisasi program dan keberadaan KWT Mekar Indah, pelaksanaan kegiatan penyuluhan, dan praktik atau demostrasi dapat dilihat pada gambar berikut.
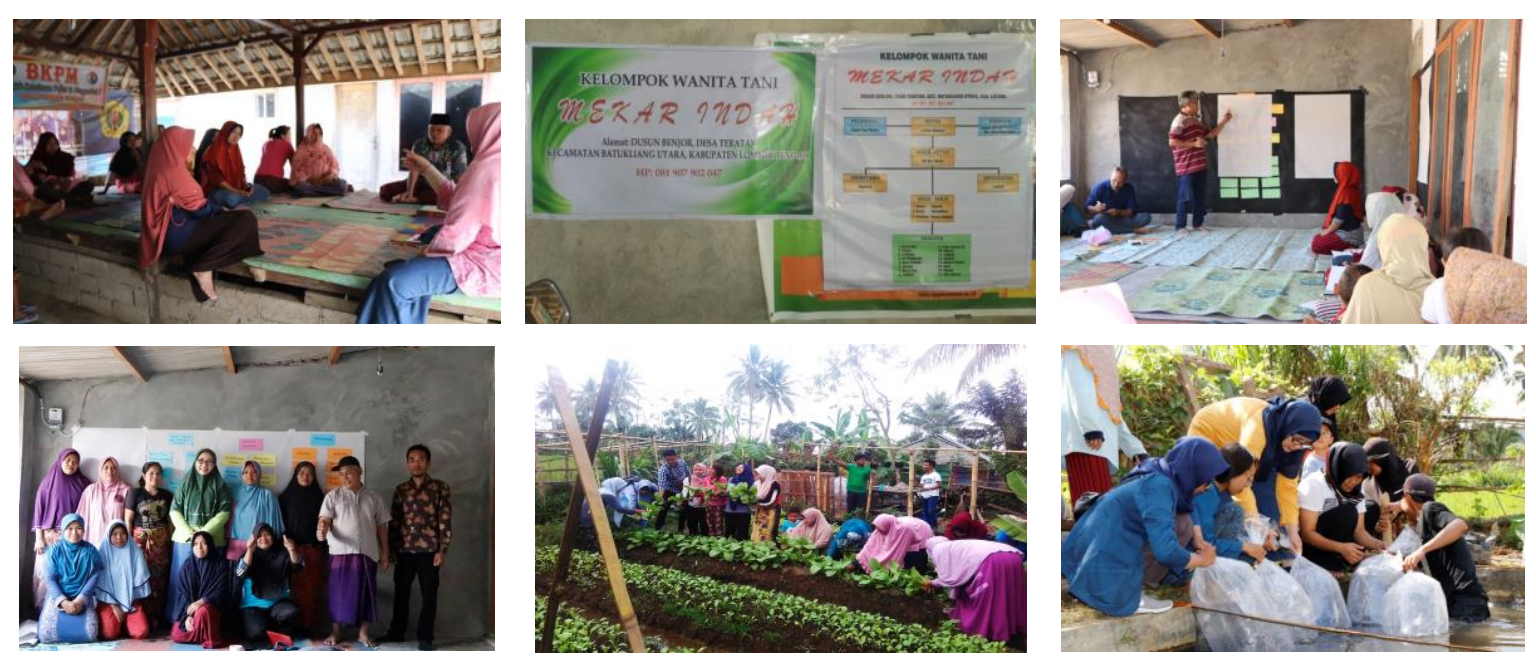

Gambar 1. Sosialisasi program pengabdian kepada masyarakat (atas kiri), Struktur organisasi KWT Mekar Indah (atas tengah), Penyuluhan tentang pentingnya berkelompok (atas kanan), Sosialisasi keberadaan KWT Mekar Indah kepada PPL PNS dan Penyuluh Swadaya (bawah kiri), Proses pembibitan, penanaman, dan panen sayuran (bawah tengah), dan Pelepasan ikan di keramba (bawah kanan).

3) Berdasarkan hasil evaluasi yang dilakukan kelompok mengenai memelihara ikan dalam keramba, kelompok melakukan perubahan perencanaan yaitu kelompok ingin memelihara ikan di kolam kelompok. Setelah berdiskusi bersama seluruh anggota kelompok dan adanya partisipasi anggota secara fisik, materi, tenaga dan gagasan, akhirnya kelompok telah mampu memiliki kolam sebagai hasil kerjasama anggota kelompok dan melakukan pemeliharaan ikan air tawar sebagai usaha dan sumber pangan hewani rumah tangga kelompok 
4) Penyuluhan pentingnya mengkonsumsi pangan beragam dan bergizi bagi setiap individu dalam rumah tangga, telah membuat peserta memiliki peningkatan pemahaman mengenai susunan pangan dan jumlah makanan serta manfaat konsumsi pangan beragam dan bergizi. Selain itu, melalui lomba dalam rangka memperingati hari kemerdekaan 17 Agustus 2019, peserta telah mampu menyusun menu dan menyediakan makanan yang beragam dan bergizi.

\section{Tahap Evaluasi}

Tahap evaluasi pelaksanaan kegiatan dilakukan di awal dan akhir kegiatan. Evaluasi awal dilakukan sebelum kegiatan sosialisasi program. Evaluasi akhir dilakukan setelah terlaksananya seluruh rangkaian kegiatan penyuluhan, dan lomba menyusun menu dan menyediakan makanan yang beragam dan bergizi. Hal ini dilakukan untuk mengetahui sejauhmana perubahan pengetahuan, sikap dan keterampilan peserta terkait dengan kemampuan sosial, manajerial, dan teknis sebelum kegiatan penyuluhan dan setelah penyuluhan. Selain itu, juga untuk mengetahui perbaikanperbaikan materi terkait dengan keberlanjutan program. Berdasarkan hasil pelaksanan evaluasi awal dan akhir, diketahui bahwa telah terjadi perubahan kemampuan perempuan secara sosial, manajerial, dan teknis. Selain itu, terjadi peningkatan pengetahuan mengenai dampak jika setiap individu dalam rumah tangga tidak mengkonsumsi makanan yang beragam dan bergizi sejak masih dalam kandungan.

Tabel 2. Rata-rata perolehan skor evaluasi awal dan akhir

\begin{tabular}{lcc}
\hline \multicolumn{1}{c}{ Uraian } & Evaluasi Awal & Evaluasi Akhir \\
\hline Kemampuan Sosial & 5,2 & 40 \\
Kemampuan Manajerial & 13 & 27,9 \\
Kemampuan Teknis & 14,5 & 19,6 \\
Dampak & 3 & 7,4 \\
\hline Total & 35,9 & 94,4 \\
\hline
\end{tabular}

Selain keberhasilan diperoleh dari pelaksanaan program, terdapat juga kendala dalam pelaksanan dan keberlanjutan program, terutama pelaksanaan pemeliharaan ikan. Ke depannnya, pemeliharaan ikan air tawar oleh kelompok tidak saja hanya untuk memenuhi kebutuan pangan hewani anggota kelompok, melainkan dikembangkan menjadi usaha kelompok untuk meningkatkan pendapatan dan kesejahteraan anggota kelompok. Oleh karena itu, pengembangan usaha kelompok perlu dilakukan dengan memberikan pengetahuan dan keterampilan mengenai budidaya ikan untuk kepentingan bisnis, bantuan modal, administrasi, manajemen keuangan, dan proses pendampingan.

\section{KESIMPULAN DAN SARAN}

Telah terjadi peningkatan kemampuan sosial peserta yang ditunjukkan dengan telah terbentuknya KWT Mekar Indah sebagai wadah belajar, bekerja sama dan mengembangkan usaha kelompok. Demikian pula halnya dengan peningkatan kemampuan manajerial peserta yang ditunjukkan dengan adanya kemampuan dalam merencanakan dan mengevaluasi kegiatan kelompok untuk perbaikan perencanaan kelompok berikutnya. Peningkatan kemampuan teknis peserta ditunjukkan dengan kemampuan peserta dalam melakukan pembibitan dan penanaman sayuran di lahan pekarangan, memelihara ikan di keramba dan di kolam kelompok, dan menyediakan masakan yang beragam dan bergizi. Selain itu, telah terjadi juga peningkatan pengetahuan mengenai manfaat jika mengkonsumsi makanan yang beragam dan bergizi bagi setiap individu sejak dalam kandungan.

Mengingat bahwa keberadaan KWT Mekar Indah di Dusun Benjor adalah masih baru, maka untuk keberlanjutan program KWT Mekar Indah dipandang perlu dilakukan pendampingan terhadap 
KWT Mekar Indah untuk memfasilitasi upaya pengusulan legalitas keberadaan KWT Mekar Indah ke Dinas Pertanian Kabupaten Lombok Barat. Selain itu, karena adanya keterbatasan kapasitas usaha dan ekonomi kelompok untuk mengembangkan usaha budidaya usaha budidaya ikan, maka disarankan dilakukan kegiatan peningkatan kapasitas usaha dan ekonomi kelompok dan pendampingan.

\section{Ucapan Terima Kasih}

Penulis mengucapkan terima kasih kepada Lembaga Penelitian dan Pengabdian kepada Masyarakat, Universitas Mataram yang telah membiayai kegiatan Pengabdian Kepada Masyarakat ini melalui Dana DIPA BLU (PNPB) Universitas MataramTahun Anggaran 2019.

\section{DAFTAR PUSTAKA}

Firmansyah, Afzalani, Farhan, M. 2010. Keanekaragaman dan kecukupan konsumsi pangan hewani dalam hubungannya dengan kualitas sumberdaya manusia keluarga di Provinsi Jambi. Jurnal Penelitian Universitas Jambi: Seri Humaniora, 1(12): 63-70, : http://onlinejournal.unja.ac.id/index.php/humaniora/article/view/2015/191.

Hayati, Sahidu, A., Muktasam, Bahry, J. 2018a. Peranan Penyuluh dan Perilaku Perempuan Tani dalam Mendukung Ketahanan Pangan Rumah Tangga di Lahan Sawah dan Lahan Kering di Kabbupaten Lombok Tengah. Prosiding Seminar Nasional Teknologi Dan Rekayasa Sosial Ekonomi Berkelanjutan Untuk Kedaulatan Pangan Dan Energi Kawasan Pulau-Pulau Kecil. Mataram, 27 Oktober.

Hayati, Sahidu, A., Muktasam, Bahry, J. 2018b. Pengaruh Karakteristik Personal Dan Sosial Ekonomi Perempuan Tani Terhadap Peningkatan Ketahanan Pangan Rumah Tangga di Kecamatan Praya Barat Kabupaten Lombok Tengah. Prosiding Seminar Nasional Teknologi Dan Rekayasa Sosial Ekonomi Berkelanjutan Untuk Kedaulatan Pangan Dan Energi Kawasan Pulau-Pulau Kecil. Mataram, 27 Oktober.

Hayati, 2015 a. Partisipasi Perempuan Tani Dalam Mencapai Ketahanan Pangan Rumah Tangga (Kasus di Kabupaten Lombok Timur Provinsi Nusa Tenggara Barat). Disertasi. Program Pascasarjana Ilmu Penyuluhan, Institut Pertanian Bogor. Bogor.

Hayati, Amanah, S., Hubeis, A.V., Tjitropranoto, P. 2015 b. Kemampuan Perempuan Tani dalam Mendukung Ketahanan Pangan Rumah Tangga. Jurnal Ilmu-ilmu Sosial dan Humaniora, 3

(17): 229-235. http://jurnal.unpad.ac.id/sosiohumaniora/article/view/8340/6614

Zakaria, H., Amanah, S., Hubeis, A.V., Tjitropranoto, P. 2014.Participation of Female Farmers in Achieving Household Food Security. Asian Journal of Agricultural and Food Sciences (AJAFS), 6(2): 533-541. https://ajouronline.com/index.php/AJAFS/article/view/1902/0

Setiawan, Iwan. 2012. Dinamika Pemberdayaan Petani: Sebuah Refleksi dan Generalisasi di Jawa Barat. Bandung: Widya Padjadjaran

Suhardjo. 1998. Dampak El-Nino dan krisis moneter pada ketersediaan, akses dan distribusi pangan. Jakarta: PT Sabena Utama.

Sumardjo. 2012. Penyuluhan dalam Pembangunan Pertanian. Di dalam Merevolusi Revolusi Hijau. Pemikiran Guru Besar IPB. Bogor: IPB Press.

World Bank. 2009. Gender in Agriculture sourcebook. The World Bank, FAO, IFAD. Washington, DC 